\title{
A STUDY ON COGNITIVE STYLE AMONG HIGH SCHOOL TEACHERS WORKING IN TRIBAL SCHOOLS
}

\author{
U.Narayanasamy ${ }^{1}$, Dr.V.Vasudevan ${ }^{2}$
}

${ }^{1}$ Ph.D Research Scholar, Department of Educational Psychology, Teachers Education University, Karapakkam,Chennai-97,India

${ }^{2}$ Assistant Professor, Department of Educational Psychology Tamil Nadu

, Tamil Nadu Teachers Education

University, Karapakkam,Chennai-97,India

\section{ABSTRACT}

The present study has been conducted to find out the patterns of cognitive styles among high school teachers working in tribal schools. The sample for the investigation was drawn from the high school teachers to working in tribal schools located in thiruppathur district, Tamilnadu state by using simple random sampling technique. It comprises 120 high school teachers. Cognitive Style Inventory (CSI) developed by Praveen Kumar Jha in this Standardized tool was used in the present study. The study revealed that there is a significant difference in the patterns of cognitive styles among high school teachers working in tribal schools with respect to their gender. The study also revealed that there is no significant difference in the patterns of cognitive style among school teachers working in tribal schools with respect to their locality and academic streams.

KEYWORDS : Cognitive style, Tribal Schools, High School Teachers.

Article Received: 10 August 2020, Revised: 25 October 2020, Accepted: 18 November 2020

\section{INTRODUCTION}

All individuals possess unique qualities and characteristics that influence how their learning best occurs in different settings and situations. Individuals who know and understand their own particular cognitive styles are able to understand themselves and their unique preferences towards solving problems or confronting issues. In addition, within the teaching and learning environment, knowledge of teacher and student cognitive style preferences assists educators to better understand their teachers and students. As we all know teaching is a dynamic activity. It unfolds a world of knowledge, information, experience and education.

Cognitive style is defined by Witkin, Moore, Goodenough, and Cox (1977) as the individual way in which a person perceives, thinks, learns, solves problems, and relates to others. Messick (1984) defined cognitive styles as consistent individual ways of organizing and processing information and experience. Cognitive styles defined as the way people perceive stimuli and how they use this information to guide their behaviour (i.e., thinking, feeling, actions (Allinson \& Hayes, 1998). Cognitive style referred to a psychological dimension representing consistencies in an
It is a highly skilled job and requires proper training and preparation on the part of teacher. Nevertheless the cognitive styles of teachers influence their teaching styles. Cognitive styles may impact on their behaviour. Cognitive styles are important in development of teachers in their personality. It may help to achieve their performance up to mark.Cognition is a collection of mental processes that includes awareness, perception, reasoning, and judgment. Cognitive styles can generally be described as the manner in which information is acquired and processed.

individual's manner of cognitive functioning, particularly with respect to acquiring and processing information (Ausburn \& Ausburn, 1978).

\section{COGNITIVE STYLE}

Cognitive styles refer to the preferred way individual processes information. Unlike individual differences in abilities e.g, Gardner Guilford, Sternberg (1977) which describe peak performance styles describe a person's typical mode of thinking remembering and problem solving. Cognitive style simply denotes a tendency of an 
individual to behave in a certain manner Dunn.R and Dunn.K (1978). Messick.S (1976) usually describes Cognitive style as a way of constructing knowledge of an individual and personality dimension which influences attitudes, values and social interaction too.

The researcher felt essential to study the cognitive style of a teacher as teacher carries multilayer effect in the schools. The cognitive style influence their teaching-learning process and classroom behaviour which determines on classroom culture and student pupil teacher learning. In the context of Globalization and Information age the speed of social change and knowledge construction has taken enormous change in the field of education.

Cognitive style refers to information processing habits such as perceiving, thinking, remembering and problem solving (Goldsteinand Black Man.1978). Cognitive style is a hypothetical construct that has been developed to explain the process of perceiving, remembering, judging, appraising and problem solving. More or less it includes one's intellectual activities.In education, cognitive style refers to how the students acquire knowledge (cognition) how they process in formation (conceptualization) and how it is applied in problem solving.

\section{REVIEW OF RELATED LITERATURE}

Keeping in view the importance of review of related literature the investigators reviewed the studies conducted by the other researcher as follows;

Evans and Waring (2011) found that cognitive style was found to impact on trainees' conceptions of differentiation, trainees demonstrating higher levels of analysis and intuition had a more developed understanding of differentiation than other cognitive styles. Saroja and Amalrai (2012) indicated that Biological Science prospective teachers differ in their cognitive style and academic achievement and there was significant relationship between cognitive style and academic achievement of prospective teachers of Biological Science with reference to personal variables. Reddy (2013) found that there was no significant difference in the cognitive styles of primary school teachers due to variation in gender but significant difference was existed in the cognitive styles of primary school teachers due to variation in age and variation in Locality.

Srinivas and Nagaraju (2014) indicated that the high school Mathematics teachers possess three types of cognitive styles, namely, split cognitive style, integrated cognitive style and undifferentiated cognitive style and also found that there was a significant difference in cognitive styles of teachers based on variation in their gender and types of management of their schools. Srinivas and Gangadhar (2015) observed that the high school Biological Science teachers possess three types of cognitive styles, namely, split cognitive style, undifferentiated cognitive style and integrated cognitive style. Khandagale (2016) found that Most of the teacher educators were using moderate left brain predominantly. The numbers of teachers using mid brain were moderate whereas very few were using moderate right brain.

\section{SIGNIFICANCE OF THE STUDY}

The study has unique significance because the results of the study can be used in designing of policies to improve the performance of the tribal teachers; and through improved performance of the teachers, the education levels of the tribal students will enhance, and thereby leading to the development of holistic society that is rich due to its diversity.

It has been presumed that individual's cognitive style plays crucial role in various aspects of life, that is, development, learning, career etc. In other words, cognitive style is important in person's life. There are different cognitive styles for each person. Each of us has our own styles of learning and thinking. Knowledge of these similarities and differences is crucial in education. The sensitivity of the teachers in dealing with individual learners' differences in cognitive style in his/her classroom may be significant influence in facilitating learning. Following the identification of relative individual differences in cognitive style of students in a classroom, the teacher can provide a multiplicity of strategies and techniques to determine which seems to be most feasible in terms of class time and effectiveness for children. Moreover, the study would be helpful for the school administrators, policy makers and teachers for designing their teaching styles which would help in maximizing students' learning.

Therefore, the researcher has taken up this study to know the cognitive styles of high school teachers working in tribal schools of Thiruppathur district, Tamilnadu state on the basis of the following objectives for the present study.

\section{OBJECTIVES}

(1) To find out the cognitive styles among high school teachers working in tribal schools. 
(2) To find out the cognitive styles among high school teachers working in tribal schools with respect to gender.

(3) To find out the cognitive styles among high school teachers working in tribal schools with respect to locality.

(4).To find out the cognitive styles among high school teachers working in tribal schools with respect to academic streams.

\section{HYPOTHESES:}

(1) There is no significant difference in cognitive styles among high school teachers working in tribal schools with respect to gender.

(2) There is no significant difference in cognitive styles among high school teachers working in tribal schools with respect to locality.

(3) There no significant difference in cognitive styles among high school teachers working in tribal schools with respect to academic streams.

\section{METHOD:}

Descriptive survey research method has been used in present study.

\section{SAMPLE:}

The sample for the investigation was drawn from the high school teachers working in tribal schools located in Tiruppathur District of Tamilnadu State. by using simple random sampling technique. It comprises 120 high school teachers working in tribal schools.

\section{TOOLS USED:}

Cognitive Style Inventory (CSI) developed by Praveen Kumar Jha was used in the present study.

\section{Reliability of the tool}

The investigator used test - retest method in establishing the reliability of the tool on Cognitive Style. The response of both the test and retest were scored and the correlation co- efficient of 0.79 was found between the test and retest. Thus the reliability of the tool was established.

\section{Hypothesis : 1}

There is no significant difference of cognitive style among high school teachers with respect to gender.

Table : 1: Cognitive style among high school teachers with respect to gender

\begin{tabular}{|l|l|l|l|l|l|l|l|}
\hline Variable & Gender & $\mathrm{N}$ & Mean & $\begin{array}{l}\text { Std } \\
\text { Deviation }\end{array}$ & t- value & $\begin{array}{l}\text { Level of } \\
\text { significance }\end{array}$ & Remarks \\
\hline \multirow{2}{*}{$\begin{array}{l}\text { Cognitive } \\
\text { style }\end{array}$} & Male & 62 & 79.32 & 8.101 & 7.924 & 0.01 & $\mathrm{~S}$ \\
\cline { 2 - 8 } & Female & 58 & 84.81 & 7.86 & & & \\
\hline
\end{tabular}

From the above table 4.1 it is inferred that $t$ value is 7.924 , which is higher than table value (2.58) at 0.01 level of significance. Therefore, the null hypothesis is rejected. Hence, it is concluded that there is a significant difference in Cognitive style among high school teachers working in tribal schools with respect to gender.

While comparing the cognitive style mean scores of the female high school teachers working in tribal schools are better than the male high school teachers working in tribal schools . 


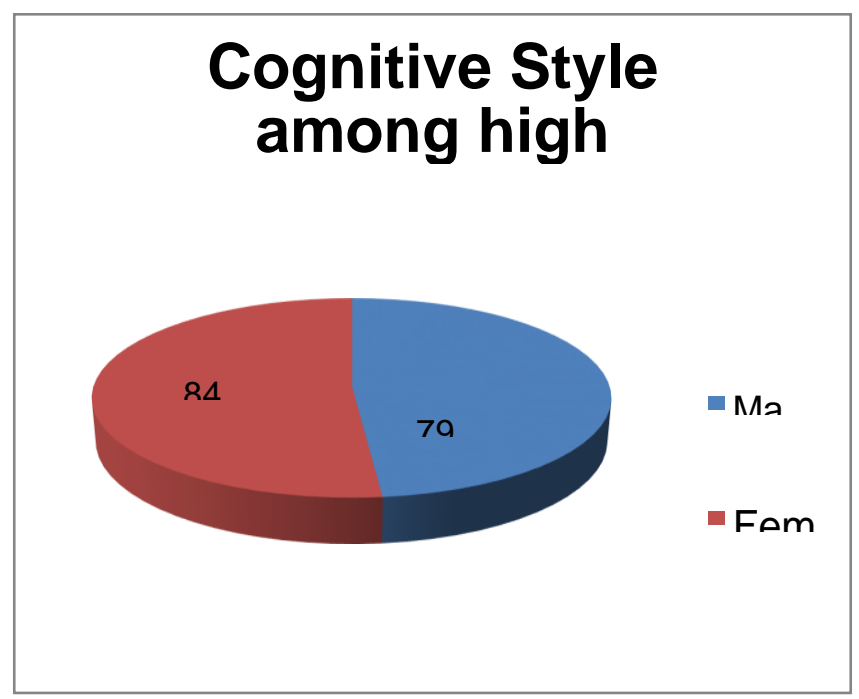

Figure : 1:Cognitive style among high school teachers with respect to gender

\section{Hypothesis :2}

There is no significant difference in cognitive style among high school teachers with respect to locality.

Table : 2: Cognitive style among high school teachers with respect to locality.

\begin{tabular}{|l|l|l|l|l|l|l|l|}
\hline Variable & Locality & $\mathrm{N}$ & Mean & $\begin{array}{l}\text { Std } \\
\text { Deviation }\end{array}$ & t- value & $\begin{array}{l}\text { Level of } \\
\text { significance }\end{array}$ & Remarks \\
\hline \multirow{2}{*}{$\begin{array}{l}\text { Cognitive } \\
\text { style }\end{array}$} & Rural & 76 & 81.18 & 8.493 & 0.058 & 0.05 & NS \\
\cline { 2 - 8 } & Urban & 49 & 81.13 & 8.138 & & \\
\hline
\end{tabular}

From the above table 2 it is inferred that $\mathrm{t}$ value is 0.058 , which is less than table value (1.96) at 0.05 level of significance. Therefore, the null hypothesis is accepted. Hence, it is concluded that there is no significant difference in Cognitive style among the high school teachers working in tribal schools with respect to locality.

For comparing the cognitive style mean scores of the rural high school teachers working in tribal schools are better than the urban high school teachers working in tribal schools.

\section{Hypothesis :3}

There is no significant difference of cognitive style among high school teachers with respect to Academic Steams. 
Table : 3: Cognitive style high school teachers with respect to Academic Steams.

\begin{tabular}{|l|l|l|l|l|l|l|l|}
\hline Variable & $\begin{array}{l}\text { Academic } \\
\text { Steams }\end{array}$ & $\mathrm{N}$ & Mean & $\begin{array}{l}\text { Std } \\
\text { Deviation }\end{array}$ & t- value & $\begin{array}{l}\text { Level of } \\
\text { significance }\end{array}$ & Remarks \\
\hline & Science & 61 & 81.91 & 8.537 & 1.293 & 0.05 & NS \\
\cline { 2 - 7 } $\begin{array}{l}\text { Cognitive } \\
\text { style }\end{array}$ & Arts & 59 & 80.91 & 8.375 & & \\
\hline
\end{tabular}

From the above table 4.3 it is inferred that $\mathrm{t}$ value is 1.293 , which is less than table value (1.96) at 0.05 level of significance. Therefore, the null hypothesis is accepted. Hence, it is concluded that there is no significant difference in Cognitive style the high school teachers working in tribal schools with respect to qualification.

While comparing the cognitive style mean scores of the science high school teachers working in tribal schools are better than the arts high school teachers working in tribal schools.

\section{MAJOR FINDINGS OF THE STUDY}

Findings related to Cognitive Style of high School Teachers working in tribal schools.

From the above table 1 it is inferred that $\mathrm{t}$ value is 7.924 , which is higher than table value (2.58) at 0.01 level of significance. Therefore, the null hypothesis is rejected. Hence, it is concluded that there is a significant difference in Cognitive style among high school teachers with respect to gender. While comparing the cognitive style mean scores of the female high school teachers are better than the male high school teachers.

From the above table 2 it is inferred that $t$ value is 0.058 , which is less than table value (1.96) at 0.05 level of significance. Therefore, the null hypothesis is accepted. Hence, it is concluded that there is no significant difference in Cognitive style among the high school teachers working in tribal schools with respect to locality. For comparing the cognitive style mean scores of the rural high school teachers working in tribal schools are better than the urban high school teachers working in tribal schools.

From the above table 3 it is inferred that $\mathrm{t}$ value is 1.293 , which is less than table value (1.96) at 0.05 level of significance. Therefore, the null hypothesis is accepted. Hence, it is concluded that there is no significant difference in Cognitive style the high school teachers working in tribal schools with respect to academic steams. While comparing the cognitive style mean scores of the science high school teachers working in tribal schools are better than the arts high school teachers working in tribal schools.

\section{SUGGESTIONS FOR FURTHER RESEARCH}

A similar study may be carried out drawing the sample from college and university teachers.

Studies may be conducted to know the cognitive styles among teachers at variable level.

$3 \mathrm{~A}$ research can be attempted to know the relationship between cognitive style and academic achievement of students.

$>$ The similar study conducted among the prospective teachers.

\section{EDUCATIONAL IMPLICATIONS}

Teachers cognitive style is paramount important in the effective teaching.

The higher mean in cognition style female high school teachers indicator that female teachers are more effect in their teaching then in their male high school teachers working in tribal area. 
The study also through the light on various strategies to improve the cognitive styles of high school teachers.

\section{CONCLUSIONS}

It is concluded that the high school teacher working in tribal schools possess integrated cognitive style further female teachers are with more integrated cognitive style then male teachers. cognition plays an important role in teaching and learning process. The school teachers possess the adequate level of cognitive style then only the student community immensely benefited. Therefore strengthening cognitive style among tribal school teachers is need of the hour. The present study will be very useful to the policy makers and administrators in the field of education.

\section{REFERENCE}

1. Ausburn, L. J., \& Ausburn, F. B. (1978). Cognitive styles: Some information and implications for instructional design. Educational Communication and Technology, 26.337-354.

2. Cataloglu, E and Ates, S. (2012). The effects of cognitive styles on naïve impetus theory application degrees of pre- service science teachers. International Journal of Science and Mathematics Education. 12(4).699-719.

3. R. Sathish, R. Manikandan, S. Silvia Priscila, B. V. Sara and R. Mahaveerakannan, "A Report on the Impact of Information Technology and Social Media on Covid-19," 2020 3rd International Conference on Intelligent Sustainable Systems (ICISS), Thoothukudi, India, 2020, pp. 224-230, doi: 10.1109/ICISS49785.2020.9316046.

4. Khandagale, V.S. (2016). A study of cognitive style among teacher educators. International Journal of Arts, Humanities and Management Studies. 2(3).12-20

5. Messick, S. (1984). The nature of cognitive styles: problems and promise in educational practice. Educational Psychologist,19.59-74.

6. Reddy, M.M. (2013). Cognitive Styles of Primary School Teachers. International Journal of Scientific Research.2(7).116-118. 